Arkansas verdict against creation science

But battle

\section{now to move}

\section{to Louisiana}

\section{Washington}

Last week's ruling by a federal judge in Little Rock, Arkansas, that a state law requiring equal treatment of "creation science" and Darwinian evolution in public schools is unconstitutional, represented a significant victory for those who have argued that, even without any explicit reference to the Bible, such laws violate the required separation of church and state.

Yet if this particular battle has been won, the war against the creationists is far from over. Indeed both the publicity given to last month's trial in Arkansas and the apparent reasonableness of the demand for "balanced treatment" have in some ways helped the creationists' case. Only minutes after Judge William Overton had announced his verdict, the state Senate in Mississippi passed by a substantial majority a virtually identical bill to the one which had just been declared unconstitutional in Arkansas.

Judge Overton was uncompromising in his criticisms of Act 590, passed hurriedly by the state legislature in March during the closing hours of its 1981 session. Declaring creation science as having "no scientific merit or educational value", he said that "the conclusion is inescapable that the only real effect of Act 590 is the advancement of religion",

The verdict came on a suit against the state which had been brought by the American Civil Liberties Union (ACLU) on behalf of 23 local religious organizations, biology teachers and school children. ACLU had asked that the judge overturn the law on the grounds that the act constitutes an establishment of religion, abridges the academic freedom of both teachers and students, and is impermissibly vague, "all in violation of the constitution and laws of the United States".

During ten days of hearings at the beginning of December, ACLU produced a series of religious and scientific witnesses to support its arguments. The former developed the claim that, whatever the wording of the act, they felt its intention to be clearly religious, since the particular set of circumstances which it implied for the origins of the Earth was only compatible, among available descriptions, with the version that appears in the Bible.

Scientists called to testify on behalf of ACLU disputed claims made by creationist groups that conventional evolutionary theory is so full of holes that the alternative hypotheses they support are at least

sufficiently plausible to deserve a hearing in a public school classroom. They also claimed that creation science did not meet the criteria for scientific theories generally accepted by the scientific community, although this was disputed by some of the creationist witnesses produced by state attorney general Steve Clark as part of his defence of the law.

In the end Judge Overton - as had been widely expected - agreed with ACLU's position. But the strength of his criticisms of the supporters of the bill surprised even those who had been expecting a favourable verdict. In a 38-page written opinion, the judge provided a detailed description of the reasons why he found none of the creationists' claims convincing and said that they had admitted that the law was "a religious crusade coupled with a desire to conceal this fact",

\title{
Creationism judged a religion, not science
}

\section{Washington}

In his verdict, Judge William Overton said that the evidence presented during the ten-day trial "established that the definition of 'creation science' has as its unmentioned reference the first 11 chapters of Genesis", and that "references to the pervasive nature of religious concepts in creation science texts amply demonstrate why state entanglement with religion is inevitable" under the Arkansas law, referred to as Act 590.

"The two-model approach of the creationists is simply a contrived dualism which has no scientific factual basis or Iegitimate educational purpose", Judge Overton wrote. "The emphasis on origins as an aspect of the theory of evolution is peculiar to creationist literature. Although the subject of origins of life is within the province of biology, the scientific community does not consider origins of life a part of evolutionary theory.",

In line with arguments that had been presented by the American Civil Liberties Union, Judge Overton stated that the essential characteristics of science were: (1) that it is guided by natural law; (2) that it has to be explanatory by reference to natural law; (3) that it is testable against the empirical world; (4) that its conclusions are tentative, that is, are not necessarily the final word; and (5) that it is falsifiable. Creation science, he said, as defined in the Arkansas act, failed to meet these essential requirements.

"Some of the state's witnesses suggested that the scientific community was 'close-minded' on the subject of creationism and that explained the lack of acceptance of the creation science
The judge criticized the creationists for not taking data and weighing them against alternative scientific data in an empirical way to reach their conclusions. Rather, he said, "they take the literal wording of Genesis and attempt to find scientific support for it"'.

The verdict was, predictably, welcomed with relief by the scientific community. The American Association for the Advancement of Science, whose annual meeting in Washington last week had spent much time discussing the implications of the creationist controversy, issued a statement saying that, in Arkansas at least, "teachers now can get back to teaching science, and students can get back to learning",

Similarly the National Association of Biology Teachers, co-plaintiffs in the ACLU suit, said that it was "gratified" by arguments," Judge Overton wrote. "Yet no witness produced a scientific article for which publication had been refused. Perhaps some members of the scientific community are resistant to new ideas. It is, however, inconceivable that such a loose-knit group of independent thinkers in all the varied fields of science could, or would, so effectively censor new scientific thought.

"The methodology employed by creationists is another factor which is indicative that their work is not science. A scientific theory must be tentative and always subject to revision or abandonment in the light of facts that are in-

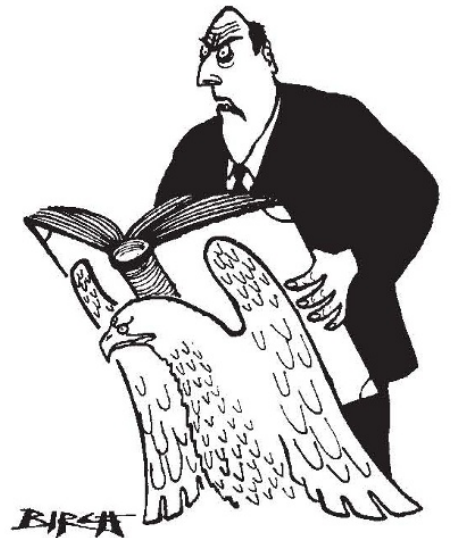

The next biology lesson is taken from the Book of Revelations....

consistent with, or falsify, a theory. A theory that is by its own terms dogmatic, absolutist and never subject to revision is not a scientific theory.",

As he had indicated during the court proceedings last month, Judge Overton made no direct reference in his ruling to the status of evolutionary theory as a science.

David Dickson 